Sadłakowski, D. (2017). The role of instant payment systems in the Polish economy. Copernican Journal of Finance \& Accounting, 6(2), 59-69. http://dx.doi.org/10.12775/CJFA.2017.011

\author{
Dominik SADkakowski* \\ Nicolaus Copernicus University in Torun
}

\title{
THE ROLE OF INSTANT PAYMENT SYSTEMS \\ IN THE POLISH ECONOMY
}

Keywords: payment system, instant payments, instant payment systems, real-time gross settlement.

J E L Classification: E58, E42.

Abstract: instant payments are one of the most important current trends in modern banking. Solutions of this type have been implemented form large-value to retail banking. The purpose of this article is to introduce broad spectrum of application of instant payment systems and to attempt to answer the question of whether the creation and further development of instant retail payment systems is important for the efficient functioning of the Polish payment system. In the process of preparing this analysis, the following methods have been used: literature analysis, secondary data analysis and case study. The security of the payment system depends largely on providing a high efficiency of its individual components. In case of polish instant payment systems there is a high level of diversification as a result of the operation of three independent instant payment systems which ensures there high performance.

Date of submission: January 3, 2017; date of acceptance: January 30, 2017.

* Contact information: dominik.sadlakowski@gmail.com, Nicolaus Copernicus University in Torun, Gagarina 13a, 87-100 Torun, Poland, phone: +48 507331 498; ORCID ID: http://orcid.org/0000-0003-0036-1546.

This article was prepared or accomplished by Dominik Sadłakowski in his personal capacity. The opinions expressed in this article are the author's own and do not reflect the view of the Narodowy Bank Polski of which the author is an employee. 


\section{INTRODUCTION}

Continued technological development determines implementing new solutions and functionalities in almost all areas of economic life, banking being one of them. The pursuit of competitiveness and the creation of stronger connections between market contributors has influenced the necessity to create systems to transfer money that would allow quick and relatively safe flow of resources between the sides of transaction. This need has impacted the development of instant payment conception. This model of settling accounts can be used not only large-value payments in central banks but also in corporate banking, and that makes it one of the fastest developing elements of payment infrastructure.

The purpose of this article is to introduce broad spectrum of application of instant payment systems to attempt to answer the question of whether the creation and further development of instant retail payment systems is important for the efficient functioning of the Polish payment system. The author of this paper presents the hypothesis that due to increasing demand for instant payment, it may be necessary to increase the capabilities of already functioning retail instant payment systems or even some changes in the way of their functioning. The subject of observations conducted by the author is the Polish payment system in which there are 3 instant payment systems: large-value SORBNET2 and retail Express Elixir and Blue Cash.

\section{THE RESEARCH METHODOLOGY}

In the process of preparing this analysis, the following methods have been used: literature analysis, secondary data analysis and case study. Polish payment systems and its selected elements have been chosen to be the case study. This research paper was created using literature on the subject, sector reports and statistical data from the analysis prepared by the Narodowy Bank Polski and chosen system operators.

\section{INSTANT PAYMENTS - THEORETICAL ASPECT}

The dynamic development of economic processes happening in the modern world outlines the necessity of constant improvement of bilateral connections between the market contributors. One of the key elements that outlines correct 
and uninterrupted money circulation in the economy is the payment system. It is the combination of connected units that allows quick and safe transfer of resources between the system contributors. In the literature, it is very commonly compared to the some kind of economy's circulatory system which proficiency is a key for country's economic stability (Górka, 2013). According to the definition presented by A. Tochmański, payment system can be described as a set of payment instruments, intermediaries, rules, procedures, processes, and - most commonly - interbank systems of funds transfers used to assure money circulation in a particular country or area of common currency (Tochmański, 2013). Therefore, it can be acknowledged that it is a particular kind of structure of tightly interconnected and mutually interacting elements. From the perspective of properly understanding the specificity of payment system, it is crucial to determine key elements that it consists of which are (Iwańczuk, 2011):

- payment instruments, used for money transfer,

- current standards and regulations of the functionality of payment instruments,

- institutions managing accounts, i.e. central and commercial banks that mediate payments,

- subjects effecting setoff and settlement of payment orders,

- law regulations connected to transfer mechanisms and functioning of payment services' market.

Now, it should be highlighted that potential disfunction of any of the mentioned elements can result in transferring created fluctuations to other parts of the structure. That in turn originates the domino effect which can cause danger to the functioning of the system as a whole or of its respective elements, e.g. interrelated institutions or specific markets. In extreme situations long-term system inefficiency can lead to damages in real economy (Polityka ..., 2015). In the case of markets with high degree of internationalisation, however, those damages can be transferred to related foreign subjects.

What turned out to be crucial for the stability of payment system is the creation and development of settlement systems based on RTGS technology. The attempts to systematise the stages of implementing those kinds of solutions in banking have been made by, for example, M.L. Bech, Ch. Preisig and K. Soramäki in the article Global Trends in Large-Value Payments (2008). In it, the authors stress that the development of modern information and telecommunication technology supported with structural changes in banks and related in- 
stitutions and the simultaneous upgrade of the expertise of central banks have had the immeasurable influence on popularising the RTGS solutions.

Figure1. Global payment system infrastructure

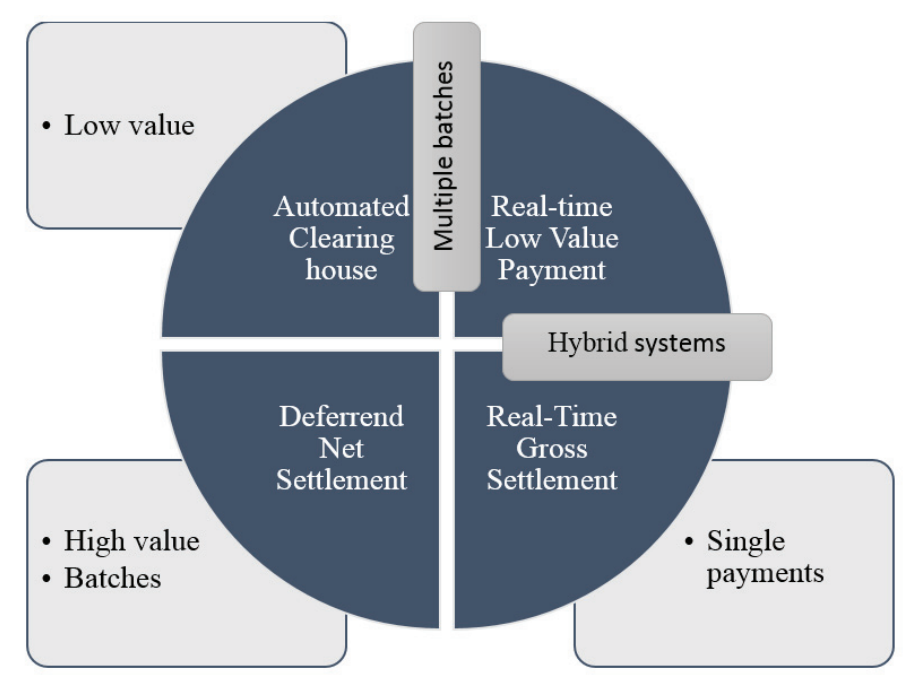

S o u r c e : the author's elaboration based on: SWIFT Response to Payment System Improvement - Public Consultation Paper, 2013.

Popularising the RTGS technology was directly connected to activating the complementary hybrid, cross-border, and offshore systems and to launching institutions, i.e. Continuous Linked Settlement Bank. It has sparked the immeasurable structural changes in financial institutions. These changes have made it possible to limit the settlement risk, reduce the transaction time (settlements in immediate mode), and optimise the prerequisites of liquidity in financial institutions. That in effect has allowed to create entirely new payment models, ones that are not limited by factors such as territorial affiliation or settlement currency. Over the years, the role of central banks has also drastically changed. Now, they have oversight function over payment systems, in particular over its key elements which are large-value payment systems (Bech, Preisig, \& Soramäki, 2008). Nowadays, numerous central banks coordinate the creation or development of the RTGS systems, often being the settlement agents at the same time and, via the banks, allowing the outside operators the settlement of performed transactions (Instant Payment System..., 2015). It is not different 
in the case of the Polish payment system. The National Bank of Poland (NBP) was the initiator of the creation of the first in Poland RTGS systems called SORB and SORBNET (now SORBNET2), which has obtained its full operational capacity in March 1996 (Paczyńska, 2004). Implementing these kind of technological solutions has, without doubt, influenced the Polish economy in the region. It was also crucial from the perspective of potential country participation in the TARGET system.

Besides RTGS systems, operated by central banks, there are also alternative forms of providing instant payment services used in retail banking, i.e. deferred net settlement systems (DNS) or deposit model systems (the so called HUB's approach). The first one can be described as a system which settles on a net basis at the end of a predefined settlement cycle (typically at the end of - but sometimes during - the business day (Glossary of terms related..., 2009). Primarily, it had been used in central banking but, due to the changes of security norms, it has been replaced by the RTGS systems. The fundamental difference between these systems is the balance between the level of liquidity and the risk. Generally, the DNS systems require maintaining much lower liquidity level but they generate greater credit risk (Wilson, 2004). Despite the fact that now DNS solutions are not so commonly used in central banking, they can be used in retail payments, for example in Polish system Blue Cash.

Deposit systems assume the functioning of an independent mediating subject (the so called Hub), in which the record of individual contributors' orders, that predates the final settlement, is created. Payments in these kind of systems are made using the resources banked on special accounts operated by central banks. Now, it should be emphasised that all executed transactions must have full coverage in the value of the invested deposits. In case of no liquidity, transactions will be stopped till the money is replaced by the contributor. The net payment is conducted in the clearing cycles and the final clearing - during the clearing session. Most systems have between 1 and 6 clearing cycles but there also are the solution's allowing its initiation in the ad-hoc mode, British Faster Payments being the example (The Global Adoption..., 2015.).

Chart 2 illustrates the current condition of the Polish payment system structure that contains its key elements, including 2 most important RTGS systems, operating large-value payments: SORBNET 2 and TARGET2-NBP and retail instant payment systems: Express Elixir and Blue Cash. 
Figure 2. Architecture of Polish payment system

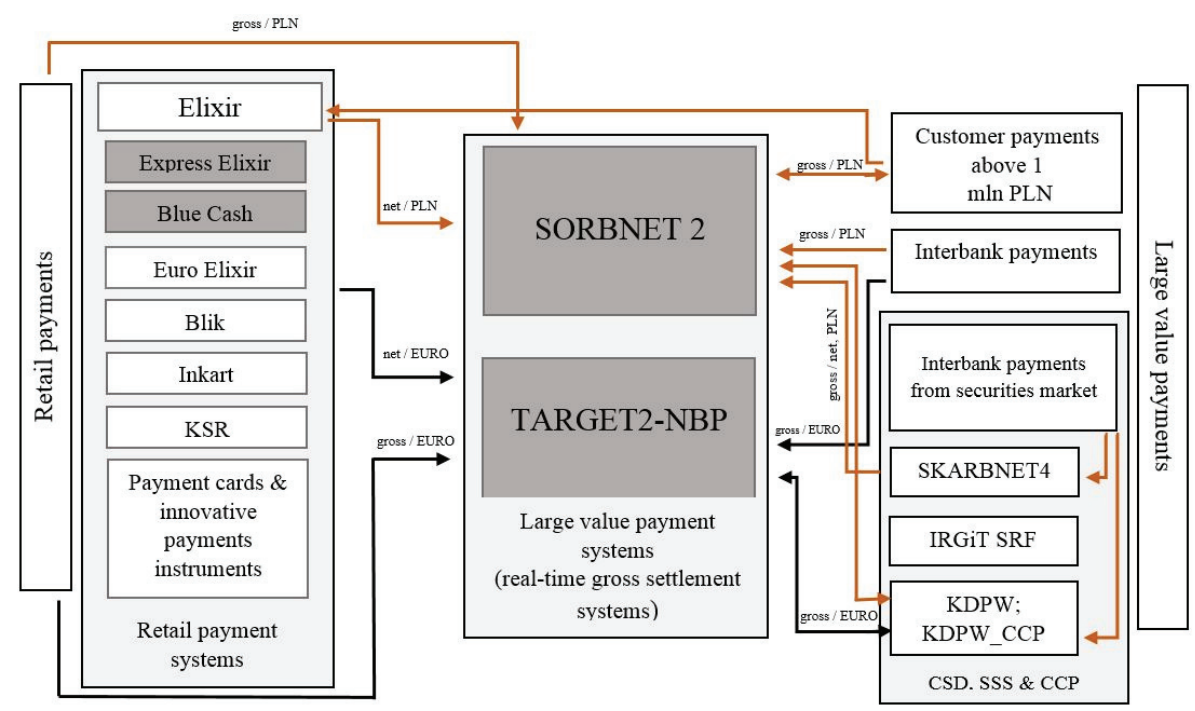

S o u r c e : the author's elaboration based on: NBP data.

\section{INSTANT PAYMENTS IN THE POLISH PAYMENT SYSTEM STRUCTURE}

Central place in the structure of payment system is held by SORBNET2, managed by the National Bank of Poland. There, the final settlement of most payment systems functioning in Poland and securities' settlement system is made. SORBNET 2 system belongs to the RTGS type systems, which means that money transfer between bank accounts is executed in the instant mode during the whole operating day. Vital characteristic of the system is also the fact that payment orders executed in it are processed and registered individually, without the necessity of a setoff with other transactions (Instant Payments Systems..., 2015). The main goal of the SORBNET2 system is the management of the current bank accounts (44 as of the first half of 2016) and of the accounts of three ancillary systems operated by: the National Clearing House (KIR), the Central Securities Depository of Poland (KDPW) and Central Securities Depository of Poland_Central Counterparty (KDPW_CCP). This system operates interbank settlement, meaning operating the bank orders and the orders of other contributors of a particular system: operations on interbank, currency, monetary, and security market, and also purchase or sale of NBP's currency and of customers' 
orders and the exchange of payment orders made by KIR (Ocena funkcjonowania polskiego systemu..., 2016).

Figure 3. The value and volume of payments settled in the SORBNET 2 system in the years 2003-2015

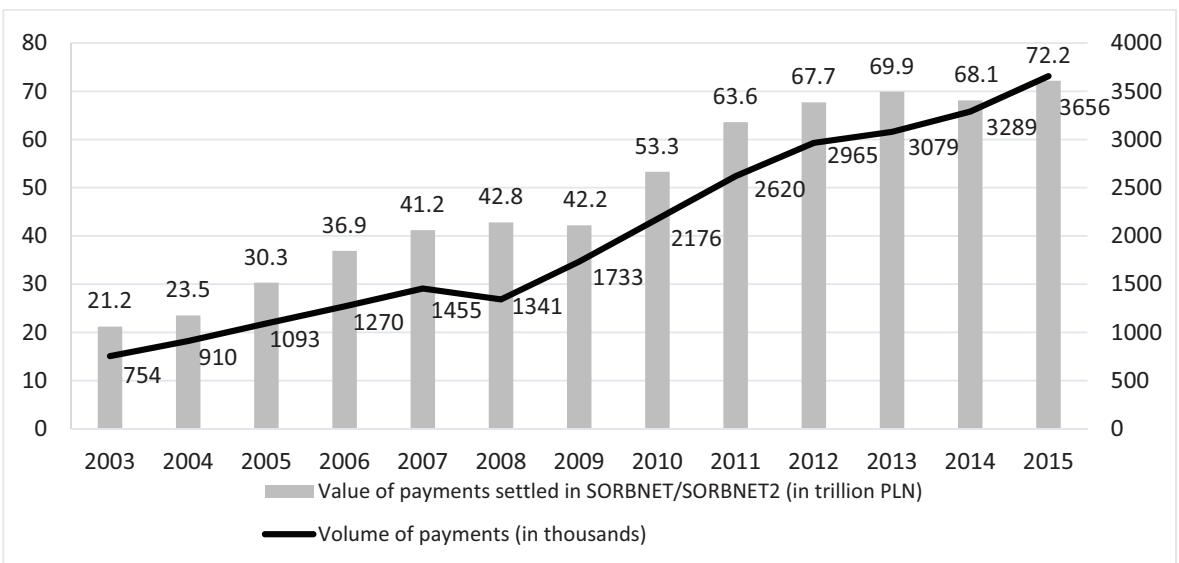

S o u r c e : the author's elaboration based on: NBP data.

The value of transactions executed in the SORBNET 2 system, in the year 2015, was over 72 trillion PLN, 40 times Poland's GDP at the time (1.79 trillion PLN (GUS)). Over $60 \%$ of this value consisted of interbank transactions, with only $7 \%$ contribution in the volume of payments. This relation greatly results from the role held by the SORBNET2 system in managing NBP's bank accounts. The remaining transaction value consists of customers' orders, 38.4\% of which were bank orders, 2.5\% National Clearing Bank's orders, 7.7\% KDPW and KDPW_CCP orders and 51.4\% were NBP's orders (Ocena funkcjonowania polskiego systemu..., 2016).

Instant payment standard are still some kind of novelty in the segment of retail payments. In the year 2015, about $50 \%$ of commerce banks in Poland have offered services of this kind to their customers, $63 \%$ of which were the biggest subjects functioning on the market (Polasik \& Piotrowski, 2016). Apart from a system SORBNET2, there are two independent instant retail payment system: Express Elixir and Blue Cash. This state is a kind of rarity, because in most European countries most payment services are provided by single entities. Such division definitely raises the level of competitiveness and quality of the services provided by individual systems. This kind of diversification also 
has a positive impact on the security of the Polish payment system. The creation of these systems has made it possible to pressure off SORBNET2 from low value retail payments.

Express Elixir System has been launched in June 2012, its operator and owner is the National Clearing House. An the end of the year 2016 there were 65 bank subject participating in the system. In contrast to the classic settlement systems, in the case of Express Elixir all resources necessary for executing the transaction are banked in the National Bank of Poland. This means that there are no intermediate subjects in the payment procedure, which in turn greatly raises the effectiveness and safety of the system. The deposits of the system contributors are assembled on the fiduciary account which is operated in the SORBNET2 system. Contributions brought by particular banks are the coverage of transactions executed by their customers. The Express Elixir system, because of its retail specifics, has an upper limit of the transaction, which amounts to 100000 PLN (expresselixir.pl).

Figure 4. The daily volume of payments in the Express Elixir and Blue Cash systems in the following semesters from the year 2013

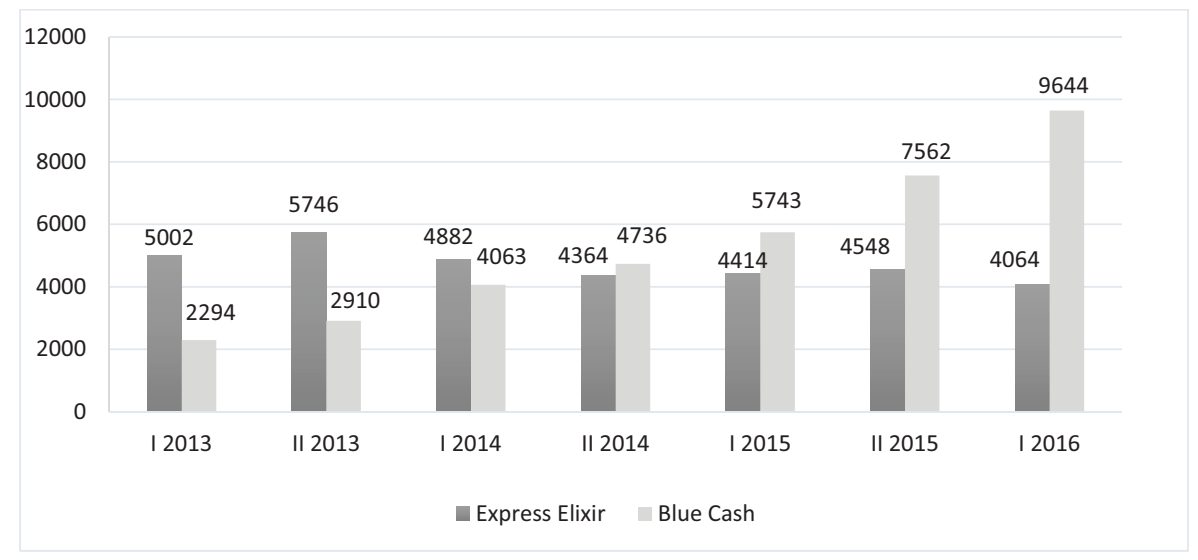

S o u r c e : author's elaboration based on: NBP data.

Blue Cash System is an alternative to the Express Elixir. In contrast to the Express Elixir he does not have one dedicated account common to all participants. The operations executed in it happen on the basis of resource transfer between bank accounts that participate in the system (bm.pl). In practice, this system is based on the transposition of interbank transfer to two interbank 
transfers, which are executed on the special intermediate accounts of the operator - Blue Media company (Kunkowski, 2013). In the year 2016, there were 112 bank institutions participating in this system. Blue Cash system is not RTGS system in the full sense of the word. Initially, in this system a maximum value of transaction was set only for 5000 PLN, but in short period of time it was decided to increase it to 20000 PLN (bm.pl).

Both systems described in the article function on the Polish market relatively short. They offer their clients homogenous service of intermediate transfers in PLN, without any time limitations. From the chart above one can observe that the number of orders executed in these systems shows a different trend. Blue Cash is, in contrast to Express Elixir, characterised by the dynamic growth of volume of executed payment orders. It can result from the fact that BlueMedia company has more system contributors, many of which are represented by the Co-operative Banks (bm.pl). However, these transactions are much more divided than in the case of Express Elixir. In the first half of 2016, the value of transactions in the Blue Cash system was 2185 bn PLN, the agreed order amount fluctuates at about 1245 PLN. In the analogous period in the Euro Elixir noted transaction value were twice as big, it was estimated to be $4439 \mathrm{bn}$ PLN, with the average order amount of 4064 PLN. Despite the leading role of Euro Elixir, it is important to point out that in the system of retail payments it is Blue Cash system that is characterised by much faster development trend. It can be seen in both the growth of the executed orders, which in the turn of the years 2015 and 2016 was over $46 \%$ and in the dynamic growth of banks participating in this system (Ocena funkcjonowania polskiego systemu..., 2016).

The average value of such transactions in those systems is far from upper limits they offer, which confirms that these are concentrated on providing their services for individual clients. The Polish payment system is lacks the alternatives to instant payment for customers whose transfers oscillate in the range above 100 thousand PLN to 1 million PLN. Consequently all customers' orders of this type (classified as retail) must be settled in SORBNET2 which is a dedicated system for settlement of large-value payments. Relatively low cost of transfer fees and their general availability may contribute to the excessive burden of this central system in the future. According to the author in order to avoid problems with the functional capacity of the SORBNET2 system, changes should be implemented in the already operated retail instant payments systems for example, by raising the upper limits of transactions. This kind of solution was implemented in the UK Faster Payments system. In this system instant 
payment limits are determined on the basis of factors such as client classification and the manner of implementing a transaction, taking into account what bank mediates the translation. Consequently, depending on the specifics of a particular transaction their upper limits range from 9999 to even $£ 250000$ (fasterpayments.org.uk).

\section{CONCLUSION}

There is no question that a working payment system is vital for the functioning of the country's economy. Its effectiveness greatly results form the possibility of making large-value payments in the real time. In this article, it has been numerously highlighted that implementing the RTGS technology have the immeasurable impact on the improvement of security and speed of transaction in the macroeconomic scale. Thanks to the SORBNET2 systems, the uninterrupted money circulation inside the country's economy.

Technological solutions drawn from the RTGS technology work also in retail payments. Poland, for some time now, is thought to be the forerunner of innovational solutions in payments technology. The fact is confirmed by the creation of two instant payment systems: Express Elixir and Blue Cash in relatively short time. The systems gain in the popularity among the customers, what is confirmed by the statistical data showing significant spike of transactions value and of volume of executed orders. Despite the growing popularity of instant payment, only few banks offer their customers these kinds of solutions and that delays in some way the popularisation of this type of payments. One of the weakness of these systems may also be a relatively low limit of transactions, especially in the case of BlueCash. According to the author, in response to growing market demand, these systems should be modified in such a way to fill this gap in a market. As a solution may serve here an example of the British Faster Payments, in which a separate branch of instant payments for business customers was created.

\section{REFERENCES}

Bech, M.L., Preisig, Ch., \& Soramäki, K. (2008). Global Trends in Large-Value Payments. FRBNY Economic Policy Review. September. New York: Federal Reserve Bank, 59-81. http://dx.doi.org/10.2139/ssrn.1141387.

Blue Media, https://bm.pl, (accessed: 28.12.2016). 
Diagnoza stanu rozwoju obrotu bezgotówkowego w Polsce (2013). Warszawa: Departament Systemu Płatniczego.

Express Elixir, https://www.expresselixir.pl (accessed: 20.12.2016).

Faster Payments, http://www.fasterpayments.org.uk (accessed: 27.01.2017).

Glossary of terms related to payment, clearing and settlement systems (2009), European Central Bank.

Górka, J. (2013). Efektywność instrumentów płatniczych w Polsce. Warszawa: Wydawnictwo Naukowe Uniwersytetu Warszawskiego. http://dx.doi.org/10.7172/97883-63962-30-2.

GUS, http://stat.gov.pl (accessed: 20.12.2016).

Instant Payments Systems - analysis of selected systems, role of the central bank and development directions (2015). Warszawa: Departament Systemu Płatniczego.

Iwańczuk, A. (2011). Systemy płatnicze i rynek płatności w Unii Europejskiej. Warszawa: Wydawnictwo CeDeWu.

Kunkowski, J. (2013). Rola i zadania integratorów płatności w polskim e-handlu. Copernican Journal of Finance \& Accounting, 2(2), 75-89. http://dx.doi.org/10.12775/ CJFA.2013.017.

Narodowy Bank Polski, http://www.nbp.pl/home.aspx?f=/systemplatniczy/dane/ dane_statystyczne.html (accessed: 28.12.2016).

Ocena funkcjonowania polskiego systemu płatniczego w I półroczu 2016 r. (2016). Warszawa: Departament Systemu Płatniczego.

Paczyńska, A. (2004). Możliwości uczestnictwa Polski w europejskim systemie płatności TARGET. Materiały i Studia, nr 171. Warszawa: NBP.

Polasik, M., \& Piotrowski, D. (2016). Payment innovations in Poland: a new approach of the banking sector to introducing payment solutions. Ekonomia i Prawo. Economics and Law, 15(1), 103-131. http://dx.doi.org/10.12775/ EiP.2016.007.

Polityka sprawowania przez Narodowy Bank Polski nadzoru systemowego w zakresie systemu płatniczego (2015). Warszawa: Departament Systemu Płatniczego.

SWIFT Response to Payment System Improvement - Public Consultation Paper (2013).

System płatniczy w Polsce (2008). Warszawa: Departament Systemu Płatniczego.

The Global Adoption of Real-Time Retail Payments Systems (RT-RPS) (2015).

Tochmański, A. (2013). Miejsce obrotu bezgotówkowego w systemie płatniczym. In. H. Żukowska, M. Żukowski (Ed.), Obrót bezgotówkowy w Polsce. Lublin: Wydawnictwo KUL.

Wilson, M. (2004). Real-Time Gross Settlement and hybrid payment systems: a comparison. Bank of England Working Paper No. 252. http://dx.doi.org/10.2139/ssrn.724042. 
